JULIET BULL

\title{
ENTITLEMENT TO COVER FOR CHRONIC PAIN SYNDROME UNDER THE ACCIDENT COMPENSATION SCHEME
}

\author{
Submitted for the LLB (Honours) Degree
}

Faculty of Law

Victoria University of Wellington

2013 


\section{Table of Contents}

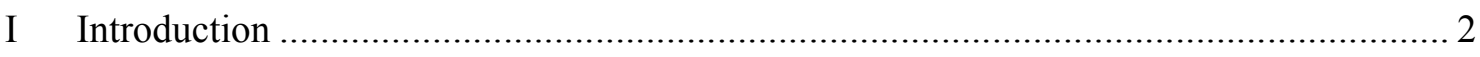

II Present Coverage of Chronic Pain Syndrome ....................................................... 2

A Overview of Chronic Pain Syndrome.............................................................. 2

B Legislative History and Relevant Provisions ..................................................... 5

C History of Entitlement for Chronic Pain Syndrome .............................................. 7

III A New Precedent? Assessing the Relevance of Allenby …......................................... 9

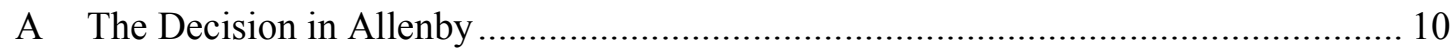

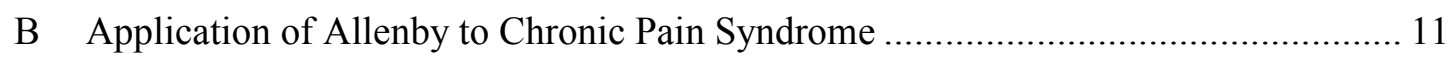

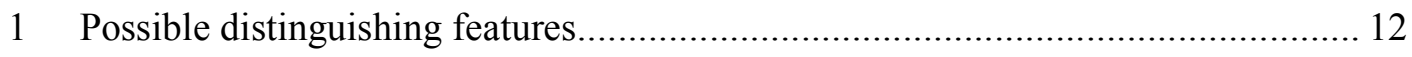

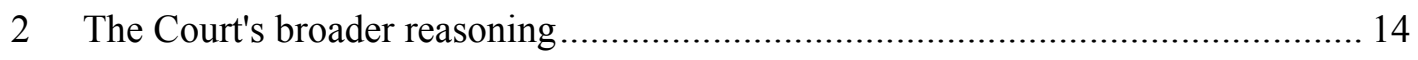

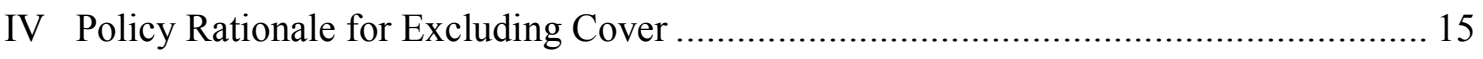

A The Woodhouse Principles .......................................................................... 16

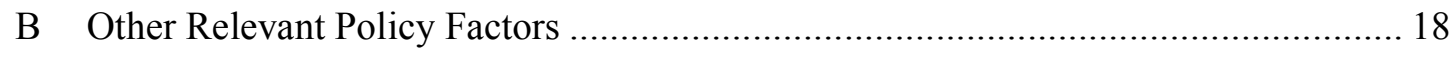

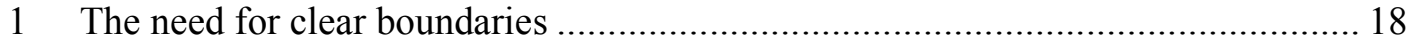

2 The purpose of the separate personal injury requirement ................................ 21

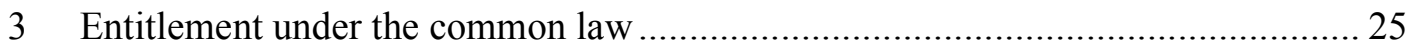

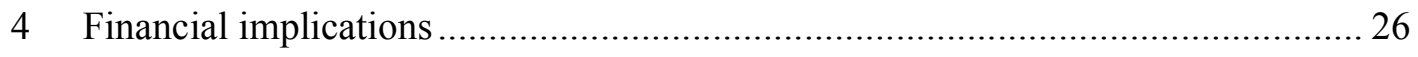

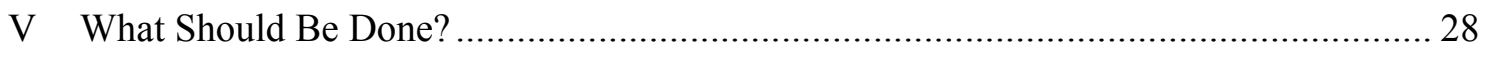

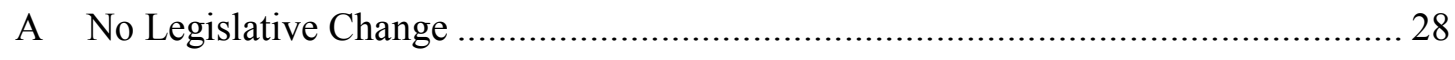

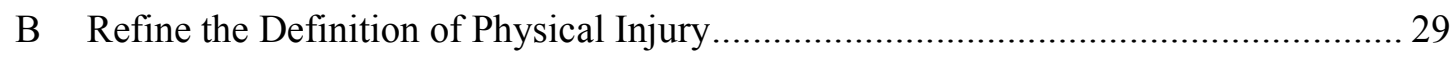

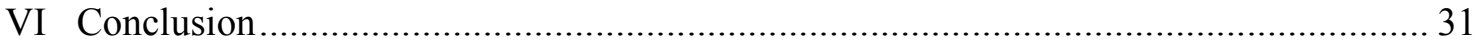

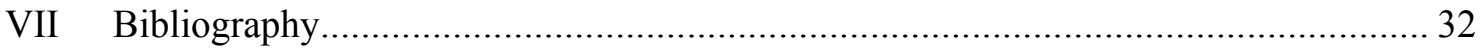


Abstract

Sufferers of primary chronic pain syndrome are not currently entitled to cover from New Zealand's Accident Compensation scheme. The Supreme Court decision in Allenby $v H$, which adopted a wider interpretation of the term "physical injury", presents an opportunity for the courts to reconsider whether chronic pain syndrome should constitute an injury. Policy factors, particularly the need to uphold the integrity of the legislation enacted by Parliament, demand that the status quo exclusion of chronic pain syndrome is maintained. A legislative amendment which clarifies this position is recommended.

Keywords

Accident compensation; chronic pain syndrome; Allenby v H; Teen v ACC. 


\section{Introduction}

Everyone has experienced feeling pain. Despite its universality, pain is not well understood. It is typically thought of as the body's automatic response to tissue injury - it has an identifiable origin, its intensity reflects the extent of that injury and it ebbs with time. ${ }^{1}$ However, this common conception only reflects one category of pain: acute pain. The other category, chronic pain, is less widely known and afflicts sufferers for a prolonged period of time. Chronic pain syndrome (CPS) is a poorly understood medical condition in which pain signals in a person's central nervous system are active, making the sufferer feel pain, when they should be inactive.

The focus of this paper is whether sufferers of primary CPS should be entitled to cover from New Zealand's Accident Compensation scheme $(\mathrm{ACC}){ }^{2}$ particularly in light of the recent Supreme Court decision in Allenby $v H$ (Allenby). While courts have held that CPS itself does not constitute a physical injury under the scheme, Allenby offers a new precedent on the meaning of physical injury and therefore presents an opportunity for the courts to reconsider the current exclusion of CPS. Policy factors point away from extending cover to sufferers of CPS and demand that the status quo is maintained. A legislative amendment which clarifies the existing position is recommended.

\section{Present Coverage of Chronic Pain Syndrome}

\section{A Overview of Chronic Pain Syndrome}

The nervous system of CPS sufferers incorrectly sends active pain signals when they should be inactive. This incorrect signalling can occur after an injury where the pain is post-traumatic but persists long after the injury has healed. In other cases, the focus of this paper, pain is primary rather than following trauma and is experienced despite there being no apparent triggering injury. For these sufferers, there has been no tissue damage like a cut or broken bone to explain why they feel pain.

\footnotetext{
${ }^{1}$ Michael S Finch "Law and the Problem of Pain" (2005) 2 U Cin L Rev 285 at 285.

${ }^{2}$ Currently represented by the Accident Compensation Act 2001.
} 
The case of Barbara Teen provides an example of primary CPS. ${ }^{3}$ Ms Teen was employed by Telecom as a Credit Service Representative, a job which involved telephone use and considerable data entry using a computer keyboard. The environment was highly stressful with commercially driven attitudes, continued monitoring of performance and few opportunities for muscle relaxation and changes of position. After seven months of work she experienced pain in her neck, shoulder, back and arms; this was diagnosed as occupational overuse syndrome caused by her work as a computer operator, later classified as CPS, regional pain syndrome or fibromyalgia. ${ }^{4}$ Although she continued working for a period Ms Teen was later deemed unfit to work so began receiving weekly ACC compensation.

Ms Teen's condition is an example of primary CPS, one of two broad categories of CPS. It is accepted that cover may be provided for the other category, post-traumatic CPS, where the pain syndrome is the consequence of or a progression from a discrete personal injury for which ACC cover is available. $^{5}$ The focus of this paper is "an entirely separate and distinct question" of entitlement where CPS is labelled primary because it arises spontaneously and is not consequential on an antecedent personal injury, as was the case with Ms Teen. ${ }^{6}$ Claimants in these situations often argue that their CPS is work-related and caused by repetitive movement in unsatisfactory working environments with poor ergonomics.

Fibromyalgia is an example of a chronic pain condition where pain is felt in several parts of the body and is not typically preceded by tissue injury. ${ }^{7}$ The

\footnotetext{
${ }^{3}$ Teen $v$ Accident Rehabilitation and Compensation Insurance Corporation [1999] NZACC 335.

${ }^{4}$ These terms were used interchangeably. In the past, cases of work-related CPS were frequently diagnosed as occupational overuse syndrome (OOS). OOS is a collective term for various conditions characterised by discomfort or persistent pain in muscles, joints and soft tissue. As OOS is a generic term a more precise diagnosis is now required by ACC, see Redshaw v Accident Compensation Corporation [2003] NZACC 61 at [9].

${ }^{5}$ Teen v Accident Compensation Corporation [2002] NZACC 244 at [36]. Cover was therefore available in the following cases, among others: Thirring $v$ Accident Compensation Corporation [2008] NZACC 135; Stevens v Accident Compensation Corporation [2008]

NZACC 167; Watson v Accident Compensation Corporation [2005] NZACC 187; and

Porima v Accident Compensation Corporation [2012] NZACC 9.

${ }^{6}$ Teen, above $\mathrm{n} 5$, at [21].

${ }^{7}$ Richard J Wurtman "Fibromyalgia and the complex regional pain syndrome: similarities in pathophysiology and treatment" (2010) 59 Metabolism 37 at 37.
} 
pain varies in intensity and is sometimes associated with sensations of crawling, numbness, or burning even though there is neither inflammation nor damage to the nervous system. ${ }^{8}$ Many sufferers have other symptoms like fatigue, depression, anxiety and difficulty concentrating. ${ }^{9}$ The prevalence of fibromyalgia in New Zealand was estimated at 1.1 per cent in Maori and 1.5 per cent in New Zealand European. ${ }^{10}$ Women are affected more frequently than men. ${ }^{11}$

It is useful to distinguish between the causes of CPS on the one hand and, on the other, the physiological mechanisms or bodily changes which take place when a person has CPS. This distinction was explained in Teen $v$ Accident Rehabilitation and Compensation Insurance Corporation (Teen): "There is no doubt that chronic pain is experienced on the basis of very real cellular, biochemical and function changes in the central and peripheral nervous system. However, these physical changes do not imply any specific origin."12 A great deal of controversy exists over the condition's causes, whereas the bodily changes which take place are reasonably well understood. $^{13}$

The range of possible causes is illustrated in the evidence provided by medical experts in Teen. While one specialist contended that workers in monotonous, repetitive jobs are predisposed to CPS, ${ }^{14}$ another specialist said that it has never been established that physical factors at work cause the condition. ${ }^{15}$ Genetic susceptibility, emotional factors, a lack of fitness and being self-driven and over-conscientious were considered possible

\footnotetext{
${ }^{8}$ At 37.

${ }^{9}$ At 37.

${ }^{10}$ Patrick Klemp, Sheila M Williams and Shelley A Stansfield "Fibromyalgia in Maori and European New Zealanders" (2002) 5 International Journal of Rheumatic Diseases 1 at 2.

${ }^{11}$ Wurtman, above $\mathrm{n} 7$, at 37.

12 Teen, above $\mathrm{n} 3$, at 13 .

${ }^{13}$ In comparison, medical experts accept that the existence of a discrete injury can cause secondary or post-traumatic CPS. See for example Thirring $v$ Accident Compensation Corporation [2008] NZACC 135 at [25] and [32].

${ }^{14}$ Teen, above $\mathrm{n} 5$, at [6].

${ }^{15}$ At [6].
} 
contributing factors. ${ }^{16}$ The specialists agreed that there is a heavy psychological component in the creation and continuation of the condition. ${ }^{17}$

In contrast, there is greater understanding of bodily changes which occur when a person has CPS. There is a consensus that the condition involves physiological changes or changes in the way bodily processes function. ${ }^{18}$ These changes take place in the pain processing of the central nervous system and mean that nerve fibres respond abnormally, incorrectly sending pain signals to the brain, when non-painful signals should be sent. ${ }^{19}$

\section{B Legislative History and Relevant Provisions}

This section outlines the legislative history of accident compensation legislation in New Zealand with an emphasis on the provisions most relevant to CPS cases.

The Royal Commission of Inquiry chaired by Sir Owen Woodhouse proposed in its report (the Woodhouse Report) that the existing worker's compensation and common law system be replaced by a comprehensive, nofault compensation scheme. Early versions of the scheme contained broad definitions. Under the Accident Compensation Act 1972 a personal injury by accident included "incapacity resulting from an occupational disease or industrial deafness..." as prescribed in the Act. $^{20}$

The Accident Rehabilitation and Compensation Insurance Act 1992 (the 1992 Act) sought to create certainty around the scheme's boundaries and, by introducing more precise definitions, limit judges' ability to interpret the statute expansively. ${ }^{21}$ The 1992 Act separated the definition of personal injury from the causes of that injury, creating two separate requirements.

\footnotetext{
${ }^{16}$ At [6].

${ }^{17}$ At [26].

${ }^{18}$ Teen, above $\mathrm{n} 3$, at 13 .

${ }^{19}$ Teen, above $\mathrm{n} 5$, at [6].

${ }^{20}$ Accident Compensation Act 1972, s 2(1). This definition was retained in the Accident Compensation Act 1982, s 2(1).

21 Stephen Todd (ed) The Law of Torts in New Zealand (5th ed, Thomson Reuters, Wellington, 2009) at 28.
} 
First, a claimant must show the existence of a personal injury. The 1992 Act defined personal injury as the "death of, or physical injuries, to a person, and any mental injury suffered by that person which is an outcome of those physical injuries to that person". 22 "Strain" and "sprain" were added as statutory examples of physical injury in $1998,{ }^{23}$ an addition which was retained in the Accident Compensation Act 2001 (the 2001 Act). ${ }^{24}$ Apart from these two examples, no further definition of physical injury is provided.

The second requirement is that the personal injury suffered was caused in one of the situations outlined in the statute. ACC generally excludes gradual process, disease or infection from cover; the exceptions to this are where the condition is work-related, caused by treatment or follows from a discrete personal injury. ${ }^{25} \mathrm{CPS}$ is a gradual process condition which arises over time, so CPS sufferers are excluded from cover unless their condition was caused by one of the aforementioned exceptions. ${ }^{26}$ As gradual process conditions caused by accident are not included on the list of exceptions, a claimant would not be covered if they argued that an accident caused their primary CPS. ${ }^{27}$ Consequently CPS sufferers typically argue that the condition is work-related. For example, substantial amounts of ironing in the home could demand repetitive strained movements leading to CPS. As the claimant could not argue that their condition was work-related they would fall within the general exclusion of gradual process injuries and would not be covered by ACC.

The 1992 Act restricted the scope of cover by introducing a strict threestage test to determine whether a gradual process, disease or infection is

${ }_{22}^{22}$ Accident Rehabilitation and Compensation Insurance Act 1992, s 4(1).

${ }^{23}$ Accident Insurance Act 1998, s 29.

${ }^{24}$ Accident Compensation Act 2001, s 26(1)(b). The title of this Act was previously the Injury Prevention, Rehabilitation, and Compensation Act 2001.

${ }_{25}^{25}$ Accident Compensation Act 2001, s 26(2).

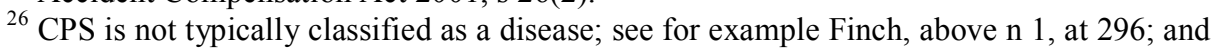
Joel Everest "Fibromyalgia and Worker's Compensation: Controversy, Problems and Injustice" (2009) 60 Ala L Rev 1031 at 1032. The distinction is not material for the purposes of ACC cover.

${ }^{27}$ As outlined above, a claimant could be entitled to ACC cover if an accident caused a covered antecedent injury which progressed into secondary CPS. This issue is outside the scope of this essay. 
work-related. $^{28}$ The 2001 Act contains largely the same wording. The personal injury must be caused by a gradual process, disease or infection and caused in the circumstances outlined in s 30(2). ${ }^{29}$ In summary, these circumstances are that a claimant's workplace or employment task has a particular characteristic which contributes to their injury, is not materially found in their non-employment activities, and the risk of suffering the injury is significantly greater for persons in that workplace or performing that task than for others. ${ }^{30}$

\section{History of Entitlement for Chronic Pain Syndrome}

This section charts the history of court decisions concerning primary CPS to show the development of the current position in which cover is denied. The earliest case on primary CPS of which the author is aware arose under the 1982 Act. The claimant's CPS was considered a disease which had arisen out of her employment. Her disease was therefore able to be covered "in the same way" as an injury and the absence of a physical injury did not prevent her from receiving ACC entitlement. ${ }^{31}$

Most cases of primary CPS have come under the 1992 Act and its successors. Proving entitlement under this legislation is harder as there are two separate requirements a claimant must show: the existence of a personal injury and that it satisfies the test of a work-related gradual process, disease or infection. This section deals with the court's approach to the first of these requirements.

The position established by the leading case of Teen, the facts of which are described above, is that CPS itself does not constitute a physical injury under the scheme. ACC terminated Ms Teen's cover after specialist physicians advised that she did not suffer a physical injury and that her condition was not work-related. She appealed the decision and her cover was initially re-instated after Judge Middleton held that her CPS constituted

\footnotetext{
${ }^{28}$ Accident Rehabilitation and Compensation Insurance Act 1992, s 7.

${ }^{29}$ Accident Compensation Act 2001, s 30(1).

${ }^{30}$ Accident Compensation Act 2001, s 30(2).

${ }^{31}$ McCulloch v Accident Compensation Corporation [2005] NZACC 109 at [5] and [19].
} 
a physical injury and was suffered as a result of workplace ergonomics. ${ }^{32} \mathrm{He}$ highlighted the acceptance from all specialists who gave evidence that CPS entailed physiological changes. ${ }^{33} \mathrm{He}$ also made the finding that the claimant's cell structure was damaged; this is a surprising conclusion given that the specialists emphasised the absence of tissue damage. ${ }^{34}$

The same conclusion was reached by Judge Beattie in the similar case Waitemata Health Ltd $v$ Ace Insurance Ltd (Waitemata). Rather than finding any cell damage, his Honour - more consistently with the medical evidence presented - concluded that the plaintiff's CPS "involve[s] physical changes and from the perspective of the person concerned it is a change which is harmful as it is a change which is causing pain". ${ }^{35}$ CPS therefore constituted a physical injury despite the absence of bodily damage. ${ }^{36}$

Six months after his decision in Waitemata, Judge Beattie came to the opposite conclusion on a rehearing of Teen. ${ }^{37}$ The definition of physical injury under the scheme, Judge Beattie held, is: ${ }^{38}$

...in accordance with the dictionary meaning "of or relating to the body as distinguished from the mind or spirit". Using the definition of physical injury in line with the natural and ordinary meaning it must therefore involve physical damage or hurt, that is bodily harm or damage.

The absence of any damage to the nervous system meant that, on the above definition, CPS itself did not constitute a physical injury. As Ms Teen could point to no other discrete injury, Judge Beattie concluded that her cover was

\footnotetext{
${ }^{32}$ Teen, above n 3, at 14 .

${ }^{33}$ At 13 .

${ }^{34}$ At 13.

${ }^{35}$ Waitemata Health Ltd $v$ Ace Insurance Ltd [2002] NZACC 68 at [47].

${ }^{36}$ At [48].

37 Judge Middleton's original decision in Teen (along with two similar decisions) was quashed on a procedural point by the High Court and a rehearing ordered in Accident Compensation Corporation v McCulloch [2001] NZAR 897 (HC).

${ }^{38}$ Teen, above $\mathrm{n} 5$, at [13]. Judge Beattie repeated this definition in Jones $v$ Accident Compensation Corporation [2002] NZACC 242 at [15], an analogous decision released on the same day at Teen.
} 
correctly revoked. ${ }^{39}$ This approach was upheld in the High Court where Wild J quoted the above definition and refused special leave to appeal. ${ }^{40}$

The decision has been referred to with approval in a number of analogous cases. $^{41}$ Until this interpretation of physical injury was reassessed in Allenby, the accepted interpretation of physical injury therefore required damage to the anatomy; bodily change accompanied by pain was insufficient. A 'Glossary of ACC terms' affirms that there is no physical injury "unless there is evidence of actual damage to the body". ${ }^{42}$ However, there are many critics of the position towards CPS who believe that "a more principled solution needs to be found to the plight of these people". ${ }^{43}$ The following two sections assess the feasibility of a claimant re-litigating the exclusion of CPS under the scheme. This reassessment requires consideration of the new precedent relevant to the issue, which is discussed in section III; and policy factors, discussed in section IV.

\section{A New Precedent? Assessing the Relevance of Allenby}

In Allenby, a case concerning pregnancy following a failed sterilisation operation, the Supreme Court adopted a broader interpretation of physical injury. This section considers the implications of that new interpretation for sufferers of CPS. Previously, the definition of physical injury adopted in Teen was not limited to situations of CPS and was also applied in the pregnancy context. In several cases the 1992 legislation was interpreted to mean that pregnancy does not constitute a physical injury. ${ }^{44}$ The Court of

\footnotetext{
${ }^{39}$ Teen, above n 5, at [36].

${ }^{40}$ Teen $v$ Accident Rehabilitation and Compensation Insurance Corporation HC

Wellington CIV-2003-485-1478, 11 November 2003 at [35].

${ }^{41}$ For example in Mura v Accident Compensation Corporation [2003] NZACC 133 at [24]; Coulter v Accident Compensation Corporation [2003] NZACC 298 at [16]; and Mitchell v Accident Compensation Corporation [2011] NZACC 247 at [16].

${ }^{42}$ Accident Compensation Corporation "Glossary of ACC terms" <http://www.acc.co.nz $>$ This orthodox position was also reflected in KL Sandford Personal injury by accident under the Accident Compensation Act: A Commentary (Accident Compensation Commission, Wellington, 1979) at 68-69.

${ }^{43}$ Ministerial Advisory Panel Report of the Ministerial Advisory Panel on Work-related Gradual Process, Disease or Infection: Section 31 Injury, Prevention, Rehabilitation and Compensation Act 2001 (Wellington, 2005) at [66].

${ }^{44}$ DK v Accident Rehabilitation and Compensation Insurance Corporation [1995] NZACC 90; [1995] NZAR 529 (DC); and MM v Accident Rehabilitation and Compensation Insurance Corporation [1996] NZACC 79.
} 
Appeal confirmed this finding in $A C C v D$ where a woman who fell pregnant following a failed tubal ligation operation had sought ACC cover. The majority in that case cited Teen with approval in holding that the term physical injury "suggest[s] a need for harm or damage". ${ }^{45}$ This meant that pregnancy was not a physical injury and ACC cover was unavailable.

\section{A The Decision in Allenby}

The Solicitor General made the same argument in Allenby as was accepted in $A C C \vee D$ : that pregnancy is not a physical injury as it is a biological process which does not damage a woman's anatomy. ${ }^{46}$ The plaintiff in Allenby suffered mental injuries after becoming pregnant following a failed sterilisation procedure.

The Supreme Court unanimously adopted a more expansive interpretation of physical injury and rejected the argument that, given the absence of bodily damage, pregnancy cannot constitute an injury. The majority judgment of Blanchard, McGrath and William Young JJ noted that pregnancy "causes significant physical changes to the woman's anatomy, which... cause discomfort and, at least ultimately, pain and suffering". ${ }^{47}$ Given that diseases or infections consequential on medical misadventure can be classed as personal injury, the majority argued that including pregnancy as a personal injury does not involve "any great stretching of language". ${ }^{48}$

Elias CJ similarly held that, if a sprain or strain amounts to personal injury, "impregnation (with its profound impact on the physiology of the woman) is properly seen as a physical injury". ${ }^{49}$ The physical impacts of pregnancy are "more than merely transitory and of greater consequence than the examples given of a strain or sprain". ${ }^{50}$ Likewise, Tipping $\mathrm{J}$ highlighted that the

\footnotetext{
${ }^{45}$ Accident Compensation Corporation v D [2008] NZCA 576 at [55] per Arnold and Ellen France JJ; William Young P dissenting.

${ }^{46}$ Allenby $v H$ [2012] NZSC 33 at [79].

${ }^{47}$ At [80].

${ }^{48}$ At $[80]$.

${ }^{49}$ At [18].

${ }^{50}$ At [19].
} 
physical changes which occur during pregnancy cause pain and suffering and are of greater consequence and duration than a strain or sprain. ${ }^{51}$

The interpretation that physical injury requires damage to the anatomy, as applied in Teen and accepted in $A C C v D$ in the pregnancy context, was therefore not upheld by the Supreme Court. The Court instead adopted a wider interpretation of the term physical injury. Physiological changes with impacts which are "more than merely transitory" compared to a strain or sprain, and cause pain and suffering, were deemed sufficient. For Tennent, "[a]dopting the position of the Supreme Court in Allenby, a physiological change causing pain amounts to a physical injury for the purposes of the accident compensation legislation". ${ }^{52}$

\section{B Application of Allenby to Chronic Pain Syndrome}

The expanded interpretation of what constitutes a physical injury adopted in Allenby arguably has implications for sufferers of primary CPS. The reasoning is reminiscent of the Waitemata decision where Judge Beattie found that CPS was a physical injury because "it is a change which is harmful as it is a change which is causing pain". ${ }^{53}$ The Judges in Allenby did not consider the broader applicability of their interpretation and the CPS issue was not considered in their judgment. Nonetheless, CPS demonstrates many of the features which the Court relied on in deeming pregnancy a physical injury. The Court's emphasis on bodily change is satisfied in the case of CPS; all medical specialists in Teen accepted that CPS involved physiological changes. ${ }^{54}$ Much like pregnancy, CPS causes substantial pain and discomfort for the sufferer and its effects are more than merely transitory - Ms Teen for example was deemed unfit to work. It too has greater impact on the person than the statutory examples of a strain or sprain. A case can therefore be advanced that Teen and the line of authority which has excluded CPS from classification as a physical injury should be revisited.

\footnotetext{
${ }^{51}$ At $[88]$.

52 Doug Tennent Accident Compensation Law (LexisNexis, Wellington, 2013) at 33.

${ }^{53}$ Waitemata Health Ltd $v$ Ace Insurance Ltd, above n 35, at [47].

${ }^{54}$ Teen, above n 3, at 13.
} 
This expanded interpretation of physical injury cannot simply be superimposed from the pregnancy context into a CPS situation to immediately undermine the conclusion in Teen. The Allenby reasoning did not rely solely on the bodily changes and impacts of pregnancy; parts of the decision do not apply in the CPS context. Possible distinguishing features, considered in turn below, are the Court's reliance on the legislative history specific to pregnancy, the scheme of the Act which separates out the various causes of personal injury, and policy factors.

\section{$1 \quad$ Possible distinguishing features}

The first distinguishing point and a major factor in the Supreme Court's decision was the "tortuous history" of accident compensation legislation. ${ }^{55}$ The scheme was extended in 1974 to specifically cover pregnancy resulting from rape. The removal of this reference to pregnancy in 1992 did not exclude pregnancy from cover; had Parliament intended this it would, reasoned the majority, have done so expressly. ${ }^{56}$ As impregnation is a physical injury covered under the scheme when it results from rape, impregnation is also a physical injury when it results from medical misadventure. ${ }^{57}$ This follows from the Act's separation of the question of personal injury from the cause of that injury, meaning the standalone definition of personal injury is the same for the various covered causes listed in the legislation. ${ }^{58}$

An analogous argument cannot be advanced in the case of CPS as there has never been express reference to the condition as a personal injury.

A second possible distinguishing feature is that primary CPS claims fall under the cause "work-related gradual process, disease or infection", whereas pregnancy is covered as either an accident or treatment injury. One might contend that the Allenby interpretation of physical injury does not apply to CPS given that it falls under a different cause. This difference is not

\footnotetext{
${ }_{56}^{55}$ Allenby, above n 46, at [68].

${ }^{56}$ At [68].

${ }^{57}$ At [76].

${ }^{58}$ At [76].
} 
material as the legislative scheme is to provide a common definition of personal injury in s 26, separate from the various causes of that injury. The Supreme Court relied on this separation in holding that the answer to whether pregnancy is a personal injury must "logically be the same in respect of both causes. The fact that one results from medical misadventure and the other from accident cannot make any difference." ${ }^{59}$ Applying this reasoning, the interpretation of physical injury should not differ in CPS cases simply because it falls under a different cause.

The Court also stated that the medical misadventure provisions (since replaced by the treatment injury regime) provide an exception to the no fault nature of the scheme, which "may suggest that they are concerned with things which are not ordinarily to be classed as physical injuries". ${ }^{60}$ This reasoning seems to introduce a different test when determining what constitutes a physical injury in the medical misadventure context. The Court's interpretation of physical injury by reference to its cause is inconsistent with their aforementioned logic concerning the separation of these two questions. Consequently, limited weight should be placed on this distinguishing point.

Policy factors which pointed towards pregnancy being covered were also relevant to the decision. Whilst recognising that the 1992 reform was in response to cost increases, Blanchard $\mathrm{J}$ considered that the costs relating to pregnancy were not substantial in the overall context of the scheme and noted that there were just 72 claims for pregnancy resulting from medical misadventure over 11 years. ${ }^{61}$ Elias CJ similarly found that there were no convincing reasons based on the statute's purpose for refusing to treat pregnancy as a physical injury. ${ }^{62}$

The Supreme Court in Allenby adopted a broader interpretation of physical injury which does not require damage to the anatomy. The case is not directly on point and therefore would not bind a lower court considering

\footnotetext{
${ }^{59}$ At [87].

${ }^{60}$ At [63].

${ }^{61}$ At [69].

${ }^{62}$ At [19].
} 
whether CPS is a physical injury. Nonetheless, and as the following discussion demonstrates, it remains arguable that the Allenby interpretation of physical injury should be applied in the CPS context.

\section{The Court's broader reasoning}

Before Allenby, cases had sought consistency in the definition of physical injury. For example, the Court of Appeal in $A C C v D$ made reference with approval to the reasoning in Teen despite the fact that one dealt with pregnancy and the other with CPS. The majority in $A C C \vee D$ also recognised that their decision would have broader consequences for the interpretation of the legislation and was not limited to the pregnancy context; as part of their reasoning, they considered that: ${ }^{63}$

...there is some force in the Corporation's submission that the Judge's approach in this case may have wider consequences for the legislation and in particular has the potential to introduce a more subjective approach to determining what is a personal injury.

Given that there is little statutory guidance defining physical injury, only the examples of a strain or sprain, it is desirable for the courts to develop a standard and generally applicable interpretation.

Furthermore, whilst the Supreme Court's reasoning was grounded to an extent in factors specific to pregnancy like the legislative history, the Court's judgment should not be so narrowly construed. The majority stated that the expression personal injury is "used in an expansive way"; ${ }^{64}$ while the Chief Justice contended that the phrase "must be interpreted in the light of the purposes of the Act which are concerned with establishing entitlements for impairment, rehabilitation, and treatment". ${ }^{65}$ This broad focus on the principle of comprehensive cover is important given its contrast to the narrow interpretation reliant on the principle of damage as adopted in $A C C v$

${ }^{63}$ Accident Compensation Corporation v D, above n 45, at [66] (emphasis added).

${ }^{64}$ Allenby, above n 46, at [69].

${ }^{65}$ At [18]. 
$D .^{66}$ For Hazel Armstrong, the decision is notable because the Court has "yet again mandated that the ACC legislation be interpreted expansively". ${ }^{67}$

Consequently, the question of ACC entitlement for CPS, previously settled by Teen as excluded from cover, could nevertheless be reopened in light of Allenby. Tennent considers that Allenby provides "an opportunity, indeed an obligation" to reconsider ACC cover for CPS. ${ }^{68}$ The issue is whether the courts should apply the wider Allenby interpretation of physical injury which emphasises bodily changes accompanied by pain and suffering, without requiring damage - beyond the pregnancy context. If it did so, CPS would constitute a physical injury and upon proving workplace causation claimants would be entitled to ACC cover. However, while Allenby provides a significant precedent by which the outcome in Teen can be questioned, the courts would not be able to rely on that precedent alone without considering the many policy factors relevant to the issue. The following section contends that policy factors point away from an expansive interpretation of physical injury and demand that the status quo be maintained.

\section{Policy Rationale for Excluding Cover}

Considering the purpose and policy behind legislation is a key part of statutory interpretation. ${ }^{69}$ Todd contends that the purpose section in the ACC legislation gives little guidance on resolving boundary issues and instead it is necessary to look to sources beyond the statute. ${ }^{70}$ The first source considered below, the principles of the Woodhouse Report, is shown to be of limited value in determining where the precise boundaries of the scheme should lie.

\footnotetext{
${ }^{66}$ Pratima Namasivayam "Wrongful Conception: An Introduction into Entitlements PostAllenby" (LLM Research Paper, Victoria University of Wellington, 2013) at 13.

${ }^{67}$ Hazel Armstrong and Kristen Bunn "Allenby v H (Medical Misadventure)" (10 May 2012) Hazel Armstrong Law < http://hazelarmstronglaw.co.nz $>$.

${ }^{68}$ Tennent, above n 52, at 34 .

${ }^{69}$ Interpretation Act 1999, s 5(1).

${ }^{70}$ Stephen Todd "The Court of Appeal, Accident Compensation and Tort Litigation" in Rick Bigwood (ed) The Permanent New Zealand Court of Appeal: Essays on the First 50 Years (Hart Publishing, Oxford, 2009) 152 at 178.
} 
The Woodhouse Report articulated five general principles which underpin the scheme, namely: community responsibility, comprehensive entitlement, complete rehabilitation, real compensation and administrative efficiency. ${ }^{71}$

Community responsibility and comprehensive entitlement were considered the foundational principles of the scheme. ${ }^{72}$ Community responsibility holds that, given the benefits that society derives from the productive work of its citizens, society should accept responsibility for those who cannot work due to physical incapacity. ${ }^{73}$ For Oliphant, the principle demands that the mere fact of incapacity which deprives an individual of the ability to contribute to society's general welfare triggers the community's obligation to provide support. $^{74}$

The Woodhouse principle of administrative efficiency is relevant to this issue but is better addressed in the context of the following section.

An emphasis on these principles points towards providing ACC cover to CPS sufferers. The incapacity experienced is great; many lose their job or their condition makes them unsuitable for previous workplace tasks. ${ }^{75}$ Community responsibility demands that society recognises the collective benefits previously contributed by these sufferers through their work and in response provides them with rehabilitation and compensation. On this view, it is counterproductive to exclude a group of incapacitated workers and, through the denial of funded rehabilitation, reduce the likelihood that they will return to work.

${ }^{71}$ New Zealand Royal Commission of Inquiry into Compensation for Personal Injury Compensation for Personal Injury in New Zealand: Report of the Royal Commission of Inquiry (Government Printer, Wellington, 1967) (The Woodhouse Report) at [4].

${ }^{72}$ At [4]-[7].

73 At [56].

${ }^{74}$ Ken Oliphant "Beyond Woodhouse: Devising New Principles for Determining ACC Boundary Issues" (2004) 35 VUWLR 915 at 917.

75 Allen and Clarke Defining Work-Related Harm: Implications for Diagnosis, Rehabilitation, Compensation and Prevention (National Occupational Health and Safety Advisory Committee, Wellington, 2009) at 123. 
Limited weight should however be placed on the Woodhouse principles. While critical to the establishment of ACC, the principles point towards a wholly comprehensive scheme which covers all forms of incapacity whether due to disease or accident. ${ }^{76}$ There are strong arguments for this form of comprehensive scheme and the Woodhouse Report itself recognised the current distinction between accident and illness as pragmatic rather than principled. $^{77}$

Nonetheless, we must work within the confines of the scheme currently in place. As McLay points out the present scheme is not "unniggardly"78 and, although we might dislike its limited scope, the courts must take seriously Parliament's failure to enact a truly comprehensive scheme. ${ }^{79}$ McLay suggests that: ${ }^{80}$

Rather than focussing solely on the Woodhouse principle of 'comprehensive entitlement', the overriding concern of courts in considering cases under the ACC scheme ought to be the integrity of the legislation actually given to us by Parliament. Where possible, judges might refer to Sir Owen Woodhouse's grand vision, but until we actually go about implementing that vision fully, integrity ought to demand that we take seriously the often quite deliberate gaps in entitlement.

The deliberate gaps to which McLay refers were incorporated in the 1992 legislation, as largely re-enacted in 1998 and 2001. Its purpose was to draw back from Woodhouse's vision in favour of a universal scheme. ${ }^{81}$ Although the Government which implemented the 1992 reforms confirmed that the

\footnotetext{
${ }^{76}$ Oliphant, above $\mathrm{n} 74$, at 915.

77 The Woodhouse Report, above n 71, at [17]. For further discussion of whether a more comprehensive scheme would be desirable see, for example, New Zealand Law Commission Personal Injury: Prevention and Recovery: Report on the Accident Compensation Scheme (NZLC R4, Wellington 1988); and Grant Duncan "Boundary Disputes in the ACC Scheme and the No-Fault Principle" [2008] NZ L Rev 27.

${ }^{78}$ See Accident Compensation Corporation v Mitchell [1992] 2 NZLR 436 (CA) at 438 per Richardson $\mathrm{J}$ for the original quote to which McLay is referring.

${ }^{79}$ Geoff McLay "Accident Compensation - What's the Common Law Got to Do With It?" [2008] NZ L Rev 55 at 73.

${ }^{80}$ At 74 .

${ }^{81}$ Todd, above n 70 , at 178 .
} 
Woodhouse principles remained sound, ${ }^{82}$ their continuing relevance is questionable given that the present scheme "so manifestly fails to give effect to $[$ them]". 83

Giving effect to the Woodhouse principles indicates that CPS should be covered by ACC, but also demands that all diseases be covered. The principles are general and holistic and therefore provide little assistance in determining precise boundary disputes, like the one at issue here, within the limited scheme currently in place. ${ }^{84}$ Consequently it is necessary to look beyond the Woodhouse principles for other relevant policy factors against which this specific boundary issue can be evaluated.

\section{B Other Relevant Policy Factors}

Given the limited utility of the Woodhouse principles in assessing this issue, the following section evaluates the broader interpretation of physical injury against a wider range of policy factors. These principles demand that the status quo, which excludes CPS from classification as a physical injury, is maintained. ${ }^{85}$

\section{$1 \quad$ The need for clear boundaries}

The first relevant policy factor is the need for clear boundaries marking the edges of the scheme. Given that the scheme is limited in scope, the meaning of physical injury should clearly delineate the boundary between conditions which are covered and those which are not. The status quo best achieves this clarity.

The need for clear boundaries is similar to the Woodhouse principle of administrative efficiency, which requires that benefits are distributed rapidly

${ }^{82}$ Geoffrey Palmer "New Zealand's Accident Compensation Scheme: 20 Years On" (1994) 44 U Toronto LJ 223 at 226.

${ }^{83}$ Oliphant, above n 74, at 925 .

${ }^{84}$ At 915.

${ }^{85}$ Whilst this paper considers whether CPS should constitute a physical injury from the perspective of the courts faced with this issue, the same policy arguments would apply if Parliament were considering whether to legislatively define physical injury in a manner which includes CPS. 
and without contention, but is more extensive than the original principle. ${ }^{86}$ Clear boundaries are essential because the scheme's financial viability rests on a quid pro quo calculation that generous and comprehensive compensation is possible due to the absence of costly and time-consuming litigation. Money spent by ACC litigating contentious cases reduces the "pot" of funds available to compensate claimants. The interpretation of physical injury adopted by the court should seek to mark clearly where entitlement ends and therefore limit the number of cases contesting where the precise boundaries of the scheme lie.

Adopting a broader interpretation of physical injury which includes CPS is likely to substantially increase ligation costs, uncertainty and delay. Although claimants would have overcome the first hurdle to entitlement by showing the existence of a personal injury, they must still show that their CPS was caused by their work to receive ACC cover. There is substantial disagreement in the medical community as to whether CPS can be caused by repetitive action in unsatisfactory working environments, which means that proving workplace causation is likely to require litigation.

The consensus position reached among medical experts was that CPS is not caused by work. A 1998 "Consensus Meeting" of medical experts sought to develop an agreed position on CPS and particularly fibromyalgia. Their conclusions included that there is very little evidence to support a link between work and fibromyalgia and in the context of keyboard work there is no supportive data at all. ${ }^{87}$ This was accepted in Teen when Judge Beattie not only denied the existence of a physical injury but also denied that Ms Teen had shown the required causal connection between her workplace activities and her CPS. ${ }^{88}$

This consensus position has been subject to much criticism. Judge Middleton called it "a matter of real concern" that the Consensus Meeting "appears to have been convened for the specific purpose of providing a

${ }^{86}$ The Woodhouse Report, above n 71, at [62].

${ }^{87}$ Teen, above $\mathrm{n} 3$, at 7.

${ }^{88}$ Teen, above n 5, at [37]. 
policy by which claims for [CPS] could be declined". ${ }^{89}$ One doctor called the consensus decision "premature" since there are medical professionals, including himself, who believe that CPS can be triggered by repetitive workplace actions or constrained postures. ${ }^{90}$

Some commentators have treated the problem of whether CPS is in fact caused by work as a minor issue. ${ }^{91}$ Tennent for instance cited Mitchell $v$ $A C C$ to show that it is possible to prove that CPS is work-related. ${ }^{92}$ In that case Judge Ongley, while holding that the claimant's CPS was not a covered personal injury, found that there was a temporal connection which suggested that the appellant's work had caused his CPS. ${ }^{93}$ While a temporal connection can be "an important piece of circumstantial evidence", ${ }^{94}$ several cases have held that a temporal connection is not itself sufficient to establish that a personal injury is work-related. ${ }^{95}$ Furthermore, Judge Ongley admitted that the causation analysis would have "needed closer attention" had the appellant first established the existence of a personal injury. ${ }^{96}$ Thus proving that CPS is work-related will be substantially more difficult than some commentators have concluded.

These vastly different medical opinions indicate that the adoption of a wider interpretation of physical injury would not ensure that CPS sufferers have cover. Instead, it is likely that the disagreement between medical specialists regarding causation will play out in the courts. The Woodhouse Report saw the negligence tort as a form of lottery. ${ }^{97}$ Classing CPS as a physical injury is, due to the lack of unanimity in the medical community about causation,

${ }^{89}$ Teen, above $\mathrm{n} 3$, at 12 .

90 New Zealand Press Association "Fibromyalgia sufferers could sue employers - law expert" The Royal Society of New Zealand / Te Aparangi (23 March 1998) $<$ http://www.royalsociety.org.nz $>$

${ }^{91}$ See for example Ministerial Advisory Panel, above n 43, at [66]; and Tennent, above n 52 , at 32 .

${ }^{92}$ Tennent, above n 52, at 32, discussing Mitchell v Accident Compensation Corporation [2011] NZACC 247 at [24].

${ }_{93}$ Mitchell v Accident Compensation Corporation, above n 92, at [23].

${ }_{94}$ Oliver v Accident Compensation Corporation [2008] NZACC 34 at [32].

${ }^{95}$ Gazzard v Accident Compensation Corporation [2001] NZACC 313 at [34]; Humphreys $v$ Accident Compensation Corporation [2001] NZACC 234 at [18]; and Nickolls v Accident Compensation Corporation [2000] NZACC 54 at 22.

${ }^{96}$ Mitchell v Accident Compensation Corporation, above n 92, at [18]

${ }^{97}$ The Woodhouse Report, above n 71, at [1]. 
likely to create inconsistent and fluctuating outcomes reflecting the lottery which Woodhouse sought to avoid.

In contrast, the finding in Teen successfully demarcated the boundary of the scheme by making it clear that CPS was not a physical injury. Doctors and lawyers could use this general rule to assess a client's claim and the likelihood of a successful appeal. This noticeably reduced the number of claims as, after a series of other cases in which Teen was applied, claimants have largely stopped bringing primary CPS appeals.

Drawing a clear line by which CPS sufferers are excluded from cover is harsh to those incapacitated people. However it reflects the reality that ACC is a limited scheme in which cover is systematically denied to people with non-work-related illnesses. As pointed out by Elias CJ in Allenby "the [scheme] provides cover on the basis of line-drawing which reflects policy choices". ${ }^{98}$ To ensure that limited funds are directed towards compensation and rehabilitation, where they are most useful, rather than towards litigation, these lines should be clearly defined. The existing position effectively marks the boundaries of the scheme, whereas adopting the broader interpretation of physical injury will blur its edges, promoting litigation where entitlement will be entirely dependent on the vastly different medical opinions presented in and accepted by the court.

\section{The purpose of the separate personal injury requirement}

The second relevant policy factor is the purpose of the standalone requirement that a claimant show personal injury. Since 1992 the ACC legislation has created two hurdles a claimant must overcome before they are entitled to cover. They must first prove the existence of a personal injury and then prove that it was caused in one of several listed circumstances. Requiring that claimant's first show the existence of a personal injury separate from its cause provides a key limit on the scope of ACC cover. The following section discusses how an interpretation of physical injury which

${ }^{98}$ Allenby, above n 46, at [7] per Elias CJ. 
includes CPS undermines the legislative scheme which has been in place since 1992.

The narrow interpretation of physical injury adopted in Teen, which requires damage to the anatomy, not only excludes CPS but many other medical conditions from classification as physical injuries. Professor Gorman called it "nonsense" to argue that CPS is an injury due to the body's physical changes. $^{99}$ Adopting that interpretation would mean that conditions like diabetes, migraine headaches and rheumatoid arthritis would also constitute injuries given their associated physical changes. ${ }^{100}$ "Indeed" he considered "by the definition of physical changes = injury, all diseases would be injuries." ${ }^{101}$

Adopting this wider interpretation of physical injury will therefore not only affect the scope of cover for CPS but risks increasing the number of ACC claims for other medical conditions. The standalone requirement for personal injury is seen as having an important filtering effect by limiting ACC entitlement. ${ }^{102}$ This filtering effect would be undermined if virtually any disease could be classed as a physical injury. In addition, given that psychological factors may be a cause of CPS, classifying the condition as a physical injury blurs the distinction within the legislation between physical and mental injuries.

Judge Beattie in Waitemata dismissed these concerns; he considered that even if conditions like migraines are classified as a personal injury the claimant would not be entitled to cover unless they show that it was caused in one of the required ways. ${ }^{103}$ The definition of personal injury recognises that it can include a gradual process, disease or infection but expressly excludes these from cover unless they are work-related or arise as a treatment injury. ${ }^{104}$

\footnotetext{
${ }^{99}$ Waitemata Health Ltd $v$ Ace Insurance Ltd, above n 35, at [33].

${ }^{100}$ At [33].

${ }^{101}$ At [33].

${ }^{102}$ Garton v Accident Compensation Corporation [2004] NZACC 151 at [39].

${ }^{103}$ Waitemata Health Ltd v Ace Insurance Ltd, above n 35, at [45].

${ }^{104}$ At [45].
} 
There is some strength to Judge Beattie's contention. For example, as migraines are normally classified as diseases, ${ }^{105}$ a claimant must show that the condition was work-related or caused by treatment. ${ }^{106}$ Hence the real filtering section is proving that a condition is work-related. ${ }^{107}$ Showing that an injury was caused by treatment will also be substantial hurdle to cover; a claim seeking cover for migraines following physiotherapy treatment was rejected because there was no physical injury and also no causative link. ${ }^{108}$ There is therefore no risk that migraine sufferers will suddenly be entitled en masse to ACC cover. However this does not fully address the problem. Additional litigation would likely be encouraged since the first obstacle to entitlement, showing the existence of a personal injury, would be overcome. There may be circumstances where the requisite causal connection is established meaning that cover would be available to a wider class of claimants. Defining physical injury narrowly better limits the scope of cover rather than relying on a case-by-case causation analysis as would be required if the wider interpretation were adopted.

Furthermore, classing a broader range of conditions as physical injuries is problematic because it disregards the legislative framework. As quoted in full above, McLay contends that, when dealing with cases at the boundaries of the scheme, courts must uphold the integrity of the legislation passed by Parliament and take seriously the deliberate gaps in entitlement. ${ }^{109} \mathrm{~A}$ key component in the 1992 reform was the creation of a standalone requirement for personal injury independent from its cause. Interpreting physical injury so broadly that all diseases would meet the test makes the first requirement of cover redundant. This cannot have been intended by Parliament when deliberately creating the standalone requirement and therefore fails to uphold the integrity of legislation currently in place.

Another purpose of the separate requirement for personal injury, as contended by Judge Cadenhead, is to provide an objective point of reference

${ }^{105}$ Robinson v Accident Compensation Corporation [2005] NZACC 243 at [14].

${ }_{106}$ Accident Compensation Act 2001, s 26(2).

${ }^{107}$ See Teen, above $\mathrm{n}$ 40, at [26].

${ }^{108}$ Robinson v Accident Compensation Corporation, above n 105, at [28].

${ }^{109}$ McLay, above n 79, at 74. 
by which an injury can be progressively monitored. ${ }^{110}$ He has stated on several occasions that "[w]ithout some significant external signposts this process would be fraught with difficulty". ${ }^{111}$ By adopting the proposed wider interpretation without an objective point of reference, it becomes more difficult to monitor a claimant's condition, therefore paving the way for malingering. ${ }^{112}$

Malingering is often considered a major risk in the CPS context given the subjective nature of pain. An analogy has been drawn between CPS and the Australian experience with Repetitive Strain Injury (RSI) in the 1980s. Following rapid increases in the number of RSI claims, compensation rules became more stringent, suddenly reducing the number of reported cases. ${ }^{113}$ Specialist physician Dr Alchin contended that "to cover such cases by workers compensation benefits... is in fact a potent cause of these cases". ${ }^{114}$ The provision of compensation causes or exacerbates the condition by: ${ }^{115}$

...encouraging a belief that a worker's acute but minor pain is actually sinister, as it is recognised by workers' compensation as "compensable injury" ... It therefore encourages the adoption of an invalid role and "illness behaviour", by legitimising and facilitating the role of a chronic invalid.

There are conflicting studies on the extent of the risk posed by malingering. One study found that fibromyalgia is more prevalent in Amish populations, who do not seek compensation for their condition, than non-Amish

${ }^{110}$ Garton v Accident Compensation Corporation, above n 102, at [39].

111 At [39]. Judge Cadenhead made the same point in Mura v Accident Compensation Corporation, above n 41, at [24].

112 Malingering is defined as "the intentional production of false or grossly exaggerated physical or psychological symptoms, motivated by external incentives such as avoiding military duty, avoiding work [and] obtaining financial compensation". American Psychiatric Association Diagnostic and Statistical Manual of Mental Disorders ( $4^{\text {th }}$ ed, American Psychiatric Association, Washington D.C., 1994) at 683 as cited in Daniel Slick, Elisabeth Sherman and Grant Iverson "Diagnostic Criteria for Malingered Neurocognitive Dysfunction: Proposed Standards for Clinical Practice and Research" (1999) 13 The Clinical Neuropsychologist 545 at 546.

${ }^{113}$ Gregory C Gardner "Fibromyalgia Following Trauma: Psychology or Biology?" (2000)

4 Current Review of Pain 295 at 298.

114 Teen, above n 3, at 6 .

115 At 6. 
populations. ${ }^{116}$ This counters the idea that fibromyalgia is exaggerated by sufferers motivated by financial incentives. On the other hand, a number of inexplicable anomalies were highlighted during the RSI epidemic in Australia: RSI was rare in self-employed subjects and more common in those with little job satisfaction; companies with branches in Australia and Europe noted the problem only in their Australian employees; and incidences of the condition were higher during the school holidays. ${ }^{117}$

The risk of malingering is exacerbated by the limited tests available for diagnosis. A diagnosis of fibromyalgia requires that patients "complain of widespread musculoskeletal pain and that they exhibit excessive tenderness when mild pressure... is applied at 11 or more among 18 predetermined anatomical sites". ${ }^{118}$ This "tender points test" has been subject to a great deal of criticism and validation of the results is "difficult or impossible". ${ }^{119}$ The risk of malingering is therefore substantial and, although unfortunate for legitimate sufferers of the condition, provides a further objection to providing ACC cover.

\section{Entitlement under the common law}

The scope of entitlement under the common law is an additional principle by which the wider interpretation of physical injury can be assessed. The majority in Allenby considered it problematic that health professionals may have to pay for additional insurance cover on top of compulsory ACC levies if pregnancy following failed sterilisation was not covered under the scheme. ${ }^{120}$ A large number of civil claims by CPS sufferers against their employers would therefore provide justification for extending cover to

\footnotetext{
${ }^{116}$ Kevin P White and John Thompson "Fibromyalgia syndrome in an Amish community: controlled study to determine disease and symptom prevalence" (2003) $30 \mathrm{~J}$ Rheumatology 1835 at 1835.

${ }^{117}$ PA Reilly "Fibromyalgia in the workplace: a 'management' problem" (1993) 52 Ann Rheum Dis 249 at 250.

${ }^{118}$ Frederick Wolfe and others "The American College of Rheumatology 1990 criteria for the classification of fibromyalgia" (1990) 33 Arthritis Rheum 160 at 160-172 as cited in Wurtman, above $\mathrm{n} 7$, at 37.

119 Frederick Wolfe "The Fibromyalgia Syndrome: A Consensus Report on Fibromyalgia and Disability" (1996) 23 J Rheumatology 534 at 535. For further criticism of the tender points test see Everest, above n 26, at 1038-1040.

${ }^{120}$ Allenby, above n 46, at [77].
} 
primary CPS. John Miller highlighted the possibility that employers may have to take out insurance against civil claims in addition to paying ACC levies. $^{121}$

In practice however, this author is not aware of any cases of primary CPS taken against an employer following a denial of ACC cover. In addition to the aforementioned difficulties in establishing workplace causation, it would likely be very difficult to prove that the ergonomics of a particular workplace were negligent. The scope of entitlement under the common law does not therefore provide any impetus to extend cover to CPS; there is no abundance of claims against employers which demand that they take out additional insurance.

\section{$4 \quad$ Financial implications}

A fourth factor by which the proposed interpretation of physical injury should be assessed is its financial implications. Commentators have criticised "unreflective judicial expansionism" which has threatened to undermine the scheme's fiscal sustainability. ${ }^{122}$ Given that courts cannot adjust levy rates it is problematic when expansive judicial decisions upset the financial calculations on which rates are set. ${ }^{123}$ Consequently, the financial implications of a proposed extension should have some bearing on the court's decision-making, as occurred in Allenby when the Judges considered that the low cost of their decision permitted the expansion to covering pregnancy. ${ }^{124}$ In contrast, the Department of Labour in 2007 estimated that the cost of expanding cover to work-related pain conditions was between $\$ 5.3$ and \$20.1 million per annum, likely \$10.2 million per annum. ${ }^{125}$ These substantial costs make it less appropriate for the courts to extend cover to CPS.

\footnotetext{
${ }^{121}$ New Zealand Press Association, above n 90.

${ }^{122}$ Todd, above n 70, at 178. Todd was referring here to Oliphant, above n 74, at 922-6.

${ }^{123}$ Oliphant, above n 74, at 922.

124 Allenby, above n 46, at [69].

125 Department of Labour "Paper 2: Legislative Options for Expanding Cover for WorkRelated Gradual Process, Disease, and Infection" (Wellington, 18 May 2007) at 6 (Obtained under Official Information Act 1982 request to the author).
} 
Furthermore, an analysis of the financial implications should also consider the likelihood of successful treatment. Ideally, the provision of rehabilitation by ACC means that claimants can return to work and productivity more rapidly. There are of course certain serious injuries which are covered by the scheme despite the impossibility of a return to work. Nonetheless in considering less-severe borderline cases a cost-benefit analysis by which the potential for a return to productivity can be assessed is relevant.

Extending ACC cover to CPS would not likely produce the desired return to productivity which could justify the high cost of rehabilitation. Rehabilitating CPS is a long-term and intensive process. ${ }^{126}$ It requires an expensive interdisciplinary model of care which addresses the multiple components of the pain condition, including medication, physical therapy, behavioural interventions, vocational training and evaluation. ${ }^{127}$ The treatment requires repeated assessment and adjustment and although total cure is possible it is infrequent. ${ }^{128}$ Consequently, the potential for increased productivity derived from funding rehabilitation is lower than in conditions with a clearer and more consistent path to recovery.

While the Woodhouse principles point to the adoption of a wide interpretation of physical injury which includes CPS, limited weight should be placed on them. Instead, a broader range of policy factors more appropriate to assessing precise boundary issues demands that the status quo be maintained. Given the conclusion that CPS should continue to be excluded from classification as a physical injury, the following section considers what, if any, action should be taken by Parliament.

${ }^{126}$ Department of Labour "Draft Legislative Options for Expanding Cover for WorkRelated Conditions" (Wellington, 5 April 2007) at 12 (Obtained under Official Information Act 1982 request to the author).

${ }^{127}$ Michael A Ashburn and Peter S Staats "Management of Chronic Pain" (1999) 353 The Lancet 1865 at 1865 .

${ }^{128}$ At 1865 


\section{What Should Be Done?}

\section{A No Legislative Change}

As policy reasons support the status quo position, one option is to simply do nothing and let the issue play out in the courts. Allenby provides an opportunity to re-litigate this issue in court and, as outlined above, there are convincing arguments to both distinguish Allenby from CPS cases or to read Allenby in an expansive way which undermines the reasoning adopted in Teen. It is more likely that Allenby would be limited to its facts and particular legislative history, meaning a judge would continue to apply the Teen rationale for excluding CPS from cover. ${ }^{129}$ Although the Court was willing to allow cover for pregnancy in Allenby, policy factors there including the legislative history and low cost impact pointed towards extending the scheme. Here however policy factors suggest a continuing exclusion of CPS.

Furthermore, when considering whether to expand entitlement, courts should consider the parliamentary history of legislation, including committee and commission reports and parliamentary debates. ${ }^{130}$ Legislative change which would extend cover to CPS has been suggested in government reports, ${ }^{131}$ select committee submissions, ${ }^{132}$ and briefing materials prepared for a Minister. ${ }^{133}$ The fact that, despite substantial consideration of the issue, Parliament has not passed legislation extending cover to CPS indicates that the courts should not step in to expand the

\footnotetext{
${ }^{129}$ See $R N v$ Accident Compensation Corporation [2012] NZACC 273 for an example of counsel seeking to apply the Allenby interpretation of physical injury to a factually distinct situation. Judge Ongley at [27] rejected the argument and concluded that Allenby was not relevant.

${ }^{130}$ Todd, above $\mathrm{n} 70$, at 178 .

${ }^{131}$ Ministerial Advisory Panel, above n 43, at [137].

${ }^{132}$ Ken Mackinnon "Submission to the Transport and Industrial Relations Select Committee on the Injury Prevention, Rehabilitation, and Compensation Amendment Bill (No 2) 2008" at 1-2; Michael Gibson "Submission to the Transport and Industrial Relations Select Committee on the Injury Prevention, Rehabilitation, and Compensation Amendment Bill (No 2) 2008" at [4.2]-[4.3]; and Acclaim Otago Inc "Submission to the Transport and Industrial Relations Select Committee on the Injury Prevention, Rehabilitation, and Compensation Amendment Bill (No 2) 2008" at 2.

${ }^{133}$ Department of Labour, above n 125, at [16]-[53]; and Department of Labour, above n 126 , at [42]-[56].
} 
scheme. Consequently it is unlikely that CPS will become covered through court action meaning the preferable status quo will be maintained.

\section{B Refine the Definition of Physical Injury}

A second option which upholds the status quo is a legislative amendment to refine the definition of physical injury. This could take two forms. The first is amending the provision which defines physical injury, s 26(1)(b) of the 2001 Act, to require actual damage to the anatomy. This recognises that pain cannot constitute injury and reflects the interpretation of physical injury adopted in Teen. This "pre-emptive change" would prevent the courts from adopting the Allenby precedent as justification for classing CPS as a physical injury.

Enacting such a definition would provide greater clarity for interpreters and eliminate some arguments over the appropriate boundaries of the scheme. A definition of physical injury has never been included in accident compensation legislation. Instead, with only the guidance provided by the statutory examples of strain and sprain, Parliament has left it to the courts to grapple with the correct interpretation and balance concepts of harm or damage against the purpose of the scheme. In some respects this position is unsatisfactory given that the Woodhouse Report, noting that there would be hard cases resulting from the scheme, considered that legislation should aim to define as clearly as possible what was covered and what was not. ${ }^{134}$

There are however several problems with enacting a more precise definition. It would have implications for other conditions presently covered by the scheme. For example, this amendment would undermine the reasoning in Allenby and instead reflect the finding in the earlier $A C C v D$ decision, once again excluding pregnancy from cover. This could be remedied through a specific pregnancy provision which clarifies that pregnancy constitutes a personal injury but, as in Allenby, explicitly limits cover to cases of sexual violation and treatment injury.

${ }^{134}$ The Woodhouse Report, above n 71, at [289(b)]. 
Whilst a pregnancy provision would be fairly easily implemented, the need for such a provision reflects a broader problem. The scheme is so large that it quickly becomes impractical, and requires an unrealistic level of engagement from Parliament, if changes to its scope demand a litany of specific amendments. Defining physical injury could also prevent unforeseen but principled future developments from taking place; had a narrow definition been enacted earlier, a case like Allenby would have been prevented. This amendment is therefore undesirable because it responds to a small problem - the low risk that CPS will be covered through judicial action - in an undiscerning and disproportionate way.

Consequently, a second legislative amendment is preferable. This would add a further paragraph to $\mathrm{s} 26$ which clarifies that personal injury caused by work-related gradual process, disease or infection can include pain that is a direct consequence of a lesion of the somatosensory system, meaning physical damage to the body's pain pathways. This amendment was proposed by the Department of Labour ${ }^{135}$ and supported by the Law Society. ${ }^{136}$ It codifies the status quo by maintaining the requirement of damage to the anatomy, meaning CPS would not itself constitute a physical injury. As it is limited to pain conditions the amendment retains a desirable flexibility and would not affect, for example, the classification of pregnancy as a physical injury. While the number of primary CPS claims taken to court has rapidly reduced since Teen, they have not disappeared entirely. ${ }^{137}$ The utility of this amendment is therefore to clarify the existing position, ensure consistency in its application and limit the potential for futile but costly appeals to be made.

Given the low chance that a Judge would adopt the Allenby precedent as justification for classing CPS as a physical injury, a legislative definition to prevent this is not essential. The second proposed legislative change should

\footnotetext{
${ }^{135}$ Department of Labour, above n 125, at [34].

${ }^{136}$ New Zealand Law Society "Supplementary Submission to the Transport and Industrial Relations Select Committee on the Injury Prevention, Rehabilitation, and Compensation Amendment Bill (No 2) 2008" at [4].

${ }^{137}$ See for example Mitchell v Accident Compensation Corporation [2011] NZACC 247.
} 
nonetheless be enacted as it usefully clarifies the law without wider implications for ACC entitlement.

\section{Conclusion}

New Zealanders would ultimately be best served by the enactment of a fully comprehensive compensation scheme which covers incapacity due to both accident and illness. However, this expansion must be made by Parliament and not in an ad hoc manner through the courts. Judicial interpretation of the Accident Compensation Act should instead reflect the reality that entitlement under the present scheme is tightly circumscribed. Thus, while the recent decision in Allenby provides an opportunity to reconsider whether CPS constitutes a physical injury, the status quo should be maintained. The existing position best upholds the integrity of the current legislation and clearly marks the boundaries of the scheme. Although possible, it is unlikely that the courts would use the Allenby reasoning to classify CPS a physical injury; nonetheless the recommended amendment would bring welcome clarity to this area of the law and should accordingly be enacted. 


\section{Bibliography}

A Cases

Accident Compensation Corporation v D [2007] NZAR 679 (HC).

Accident Compensation Corporation v D [2008] NZCA 576.

Accident Compensation Corporation v McCulloch [2001] NZAR 897 (HC).

Accident Compensation Corporation v Mitchell [1992] 2 NZLR 436 (CA).

Allenby v $H$ [2012] NZSC 33.

Coulter v Accident Compensation Corporation [2003] NZACC 298.

DK $v$ Accident Rehabilitation and Compensation Insurance Corporation [1995] NZACC 90; [1995] NZAR 529 (DC).

Garton v Accident Compensation Corporation [2004] NZACC 151.

Gazzard v Accident Compensation Corporation [2001] NZACC 313.

Humphreys v Accident Compensation Corporation [2001] NZACC 234.

Jones v Accident Compensation Corporation [2002] NZACC 242.

McCulloch v Accident Compensation Corporation [2005] NZACC 109.

Mitchell v Accident Compensation Corporation [2011] NZACC 247.

MM $v$ Accident Rehabilitation and Compensation Insurance Corporation [1996] NZACC 79.

Mura v Accident Compensation Corporation [2003] NZACC 133.

Nickolls v Accident Compensation Corporation [2000] NZACC 54.

Oliver v Accident Compensation Corporation [2008] NZACC 34.

Porima v Accident Compensation Corporation [2012] NZACC 9. 
Redshaw v Accident Compensation Corporation [2003] NZACC 61.

RN v Accident Compensation Corporation [2012] NZACC 273.

Robinson v Accident Compensation Corporation [2005] NZACC 243.

Stevens v Accident Compensation Corporation [2008] NZACC 167.

Teen v Accident Compensation Corporation [2002] NZACC 244.

Teen $v$ Accident Rehabilitation and Compensation Insurance Corporation [1999] NZACC 335.

Teen $v$ Accident Rehabilitation and Compensation Insurance Corporation HC Wellington CIV-2003-485-1478, 11 November 2003.

Thirring v Accident Compensation Corporation [2008] NZACC 135

Waitemata Health Ltd v Ace Insurance Ltd [2002] NZACC 68.

Watson v Accident Compensation Corporation [2005] NZACC 187.

Willis v Attorney General [1989] 3 NZLR 574 (CA).

\section{B Legislation}

Accident Compensation Act 1972.

Accident Compensation Act 1982.

Accident Compensation Act 2001.

Accident Insurance Act 1998.

Accident Rehabilitation and Compensation Insurance Act 1992.

Interpretation Act 1999.

\section{Books and Book Chapters}

Ian Campbell Compensation for personal injury in New Zealand: its rise and fall (Auckland University Press, Auckland, 1996). 
Terence G Ison Accident Compensation: A Commentary on the New Zealand Scheme (Croom Helm, London, 1980).

Geoffrey Palmer Compensation for Incapacity (Oxford University Press, Wellington, 1979).

KL Sandford Personal injury by accident under the Accident Compensation Act: A Commentary (Accident Compensation Commission, Wellington, 1979).

Doug Tennent Accident Compensation Law (LexisNexis, Wellington, 2013).

Stephen Todd "The Court of Appeal, Accident Compensation and Tort Litigation" in Rick Bigwood (ed) The Permanent New Zealand Court of Appeal: Essays on the First 50 Years (Hart Publishing, Oxford, 2009) 152.

Stephen Todd (ed) The Law of Torts in New Zealand (5th ed, Thomson Reuters, Wellington, 2009).

\section{Journal Articles}

Michael A Ashburn and Peter S Staats "Management of Chronic Pain" (1999) 353 The Lancet 1865.

Gené Stephens Connolly "Hidden Illness, Chronic Pain: The Problems of Treatment and Recognition of Fibromyalgia in the Medical Community" (2002) 5 DePaul J Health Care L 111.

Grant Duncan "Boundary Disputes in the ACC Scheme and the No-Fault Principle" [2008] NZ L Rev 27.

Joel Everest "Fibromyalgia and Worker's Compensation: Controversy, Problems and Injustice" (2009) 60 Ala L Rev 1031.

Michael S Finch "Law and the Problem of Pain" (2005) 2 U Cin L Rev 285.

Gregory C Gardner "Fibromyalgia Following Trauma: Psychology or Biology?" (2000) 4 Current Review of Pain 295. 
Richard Gaskins "Reading Woodhouse for the Twenty-First Century" [2008] NZ L Rev 11.

RJ Hayden, DS Louis and C Doro "Fibromyalgia and myofascial pain syndromes and the workers' compensation environment: an update" (2006) 5 Clin Occup Environ Med 455.

Maria Hook "New Zealand's Accident Compensation Scheme and ManMade Disease" (2008) 39 VUWLR 289.

Patrick Klemp, Sheila M Williams and Shelley A Stansfield "Fibromyalgia in Maori and European New Zealanders" (2002) 5 International Journal of Rheumatic Diseases 1.

J Langley and R Brenner "What is an injury" (2004) 10 Injury Prevention 69.

Geoff McLay "Accident Compensation - What's the Common Law Got to Do With It?" [2008] NZ L Rev 55.

John Miller "Trends in Personal Injury Litigation: the 1990s" (2003) 34 VUWLR 407.

Yasmin Moinfar "Pregnancy Following Failed Sterilisation Under the Accident Compensation Scheme" (2009) 40 VUWLR 805.

Ken Oliphant "Beyond Woodhouse: Devising New Principles for Determining ACC Boundary Issues" (2004) 35 VUWLR 915.

Geoffrey Palmer "New Zealand's Accident Compensation Scheme: 20 Years On" (1994) 44 U Toronto LJ 223.

Geoffrey Palmer "The Future of Community Responsibly" (2004) 35 VUWLR 905.

Dara E Purvis "Clinical Evidence as Gendered: Fibromyalgia Social Security Disability Claims" (2011) 20 TXJWL 85. 
PA Reilly "Fibromyalgia in the workplace: a 'management' problem" (1993) 52 Ann Rheum Dis 249.

Daniel Slick, Elisabeth Sherman and Grant Iverson "Diagnostic Criteria for Malingered Neurocognitive Dysfunction: Proposed Standards for Clinical Practice and Research" (1999) 13 The Clinical Neuropsychologist 545.

Alice Theadom and others "Women with fibromyalgia syndrome in New Zealand: the symptom experience" (2011) 124(1347) New Zealand Medical Journal 38 .

Rosemary Tobin "Common Law Actions on the Margin" [2008] NZ L Rev 7.

Kevin P White and John Thompson "Fibromyalgia syndrome in an Amish community: controlled study to determine disease and symptom prevalence" (2003) 30 J Rheumatology 1835.

Frederick Wolfe "The Fibromyalgia Syndrome: A Consensus Report on Fibromyalgia and Disability" (1996) 23 J Rheumatology 534.

Frederick Wolfe and others "The American College of Rheumatology 1990 criteria for the classification of fibromyalgia" (1990) 33 Arthritis Rheum 160.

Richard J Wurtman "Fibromyalgia and the complex regional pain syndrome: similarities in pathophysiology and treatment" (2010) 59 Metabolism 37.

\section{E Parliamentary and Government Materials}

Acclaim Otago Inc "Submission to the Transport and Industrial Relations Select Committee on the Injury Prevention, Rehabilitation, and Compensation Amendment Bill (No 2) 2008".

Department of Labour "Advice to Minister for ACC: Draft Legislative Options for Expanding Cover for Work-Related Conditions" (5 April 2007) (Obtained under Official Information Act 1982 request to the author). 
Department of Labour "Advice to Minister for ACC: Paper 2: Legislative Options for Expanding Cover for Work-Related Gradual Process, Disease, and Infection" (18 May 2007) (Obtained under Official Information Act 1982 request to the author).

Department of Labour The Injury Prevention, Rehabilitation, and Compensation Amendment Bill (No 2): Department of Labour Report to the Transport and Industrial Relations Select Committee (Wellington, May 2008).

Michael Gibson "Submission to the Transport and Industrial Relations Select Committee on the Injury Prevention, Rehabilitation, and Compensation Amendment Bill (No 2) 2008".

Ken Mackinnon "Submission to the Transport and Industrial Relations Select Committee on the Injury Prevention, Rehabilitation, and Compensation Amendment Bill (No 2) 2008".

Ministerial Advisory Panel Report of the Ministerial Advisory Panel on Work-related Gradual Process, Disease or Infection: Section 31 Injury, Prevention, Rehabilitation and Compensation Act 2001 (Wellington, 2005).

New Zealand Law Society "Supplementary Submission to the Transport and Industrial Relations Select Committee on the Injury Prevention, Rehabilitation, and Compensation Amendment Bill (No 2) 2008".

\section{F Reports}

Allen and Clarke Defining Work-Related Harm: Implications for Diagnosis, Rehabilitation, Compensation and Prevention (National Occupational Health and Safety Advisory Committee, Wellington, 2009).

New Zealand Law Commission Personal Injury: Prevention and Recovery: Report on the Accident Compensation Scheme (NZLC R4, Wellington 1988). 
New Zealand Royal Commission of Inquiry into Compensation for Personal Injury Compensation for Personal Injury in New Zealand: Report of the Royal Commission of Inquiry (Government Printer, Wellington, 1967) (The Woodhouse Report).

\section{G Dissertations}

Pratima Namasivayam "Wrongful Conception: An Introduction into Entitlements Post-Allenby" (LLM Research Paper, Victoria University of Wellington, 2013).

\section{H Internet Materials}

Accident Compensation Corporation "Glossary of ACC terms" $<$ http://www.acc.co.nz $>$

Armstrong, Hazel and Kristen Bunn "Allenby v H (Medical Misadventure)" (10 May 2012) Hazel Armstrong Law <http://hazelarmstronglaw.co.nz>.

New Zealand Press Association "Fibromyalgia sufferers could sue employers - law expert" The Royal Society of New Zealand / Te Aparangi (23 March 1998) < http://www.royalsociety.org.nz>

Word Count: The text of this paper (excluding bibliography and footnotes) comprises 7996 words. 